REPORTS OF MORPHOLOGY
Official Journal of the Scientific Society of Anatomists,
Histologists, Embryologists and Topographic Anatomists
of Ukraine
journal homepage: https://morphology-journal.com

\title{
Structural changes of duodenal mucosa enterocytes of rats in burn skin injury under experimental streptozotocin-induced diabetes mellitus
}

\author{
Cherkasov V.G., Tymoshenko I.O.
}

Bogomolets National Medical University, Kyiv, Ukraine

\section{ARTICLE INFO}

Received: 19 December, 2018

Accepted: 25 January, 2019

UDC: $616.341: 599.323 .4: 616-001.17$

\section{CORRESPONDING AUTHOR}

e-mail: iryna.tymoshenko@i.ua

Tymoshenko I.O.

\begin{abstract}
The work is devoted to the study of structural changes of enterocytes in the mucous membrane of the duodenum in a burn injury of the skin of a rat under conditions of experimental streptozotocin induced diabetes. The study was carried out on laboratory white adult rats-males weighing 180-210 g. The control group consisted of 21 animals without somatic pathology, the first experimental group consisted of 21 rats with skin burn injury, the second experimental group cleared 21 rats with skin burn and experimental streptozotocin induced diabetes. A model of experimental diabetes mellitus was reproduced by administering streptozotocin intraperitoneally once in dose of $50 \mathrm{mg} / \mathrm{kg}$ to rats. In an experimental simulation of a skin burn, two copper plates in the form of an ellipse were kept in water at $100^{\circ} \mathrm{C}$ for 10 minutes and, under ether anesthesia conditions, were applied simultaneously symmetrically on both exposed parts of the body of rats with an exposure for 10 seconds. Burn skin damage in rats was II-AB degrees - dermal surface burn (according to the old classification III-A degree) with a total area of $21-23 \%$ of the body surface with the development of burn shock. For morphological studies, the duodenum was taken, fragments of which were processed using conventional light and electron microscopy. The main criteria for assessing damage the enterocytes of the duodenal mucosa were the results studies of histological and ultrastructural data over 7, 14 and 21 days after a skin burn. The results of the studies showed that the damage of the enterocytes of the duodenal mucosa is based on deep destructive changes, which after 21 days (at the stage of septic toxemia), as a rule, are not reversible and develop against the background of significant intoxication of the organism. In the mucous membrane of the duodenum with burn injury of the skin associated with diabetes mellitus, there is a deterioration of the manifestations of the adaptive response and prolongation of destructive processes, accompanied by a violation of intercellular interactions in cytoarchitectically modified and deformed villi and crypts. Keywords: burn injury, streptozotocin-induced diabetes mellitus, morphological changes of the duodenum.
\end{abstract}

\section{Introduction}

In modern conditions of intensive industrialization and more increasing growing worldwide use of heat sources in everyday life, there is an increase in the frequency of burn traumatic injuries $[10,12,13,14,18,20]$. Deep widespread burns are characterized not only by damage to the integumentary tissues, but also cause burn disease, which is characterized by different, lasting and peculiar general morphological and functional changes of all organs and systems of the organism [16]. It is clear that burn injury of the skin causes significant changes, first of all, skin cells [15], but damage to the skin is considered to be the main pathogenic mechanism that causes the development of burn disease, the components and factors of which are: generalized catabolic response in the trauma center and in all internal organs, systemic inflammatory and apoptotic responses, endogenous intoxication and multiple organ dysfunction $[3,8,9]$.

Particularly unfavorable is the course of burn disease in the context of its association with diabetes mellitus [6, 16]. However, structural changes enterocytes of the mucous 
membrane duodenum the conditions of association burn disease with diabetes have so far remained unheeded by researchers. On this basis, the important role of duodenal dysfunction in the pathogenesis of burn disease $[4,6]$ determines the need to study the morphogenesis of destructive and regenerative processes in its mucous membrane at different times after burn injury under the conditions of the course of diabetes mellitus.

The purpose of the work was to study the structural changes of enterocytes in the mucous membrane of the duodenum in burn injury of the skin of rats under the conditions of experimental streptozotocin-induced diabetes mellitus.

\section{Materials and methods}

This research was conducted on laboratory white adult male rats weight $180-210 \mathrm{~g}$. The control group consisted of 21 animals without somatic pathology, the first experimental group consisted of 21 rats with burn skin injury, the second experimental group consisted of 21 rats with skin burn and experimental streptozotocin-induced diabetes. All studies and control of the animals were conducted in accordance with the rules for the use of the animals in the experiments, adopted by the "European Convention for the Protection of Vertebrate Animals Used for Experimental and other Scientific Purposes" (Strasbourg, 1986), "General Ethica Principles of Animal Experiments", adopted by the First National Congress On Bioethics (Kyiv, 2001), "Ethical Principles and Guidelines for Experiments on Animals: 3rd Edition" (Switzerland 2005) and the Law of Ukraine "On the Protection of Animals from Cruel Treatment" (2006). The experimental diabetes model was reproduced by administering streptozotocin to the rats intraperitoneally at a dose of $50 \mathrm{mg} / \mathrm{kg}$, pre-dissolving it in $0.1 \mathrm{M}$ citrate buffer solution $(\mathrm{pH}-4,5)$. The duration of the experiment was 1 month. The control of the development of hyperglycemia in the second experimental group was blood glucose level $-24.24 \pm 0.79 \mathrm{mmol} / \mathrm{L}$. In the control group $8.03 \pm 0.4 \mathrm{mmol} / \mathrm{L}$.

In our research, burn skin injury was caused in accordance with the widespread model among researchers Regas F.C. and Ehrlich H.P. [17], which has been slightly modified and optimized Gunas I.V. with coauthors [7]. In the experimental simulation of skin burns, two copper plates in the form of an ellipse were kept in water at $100^{\circ} \mathrm{C}$ for 10 minutes and, under the conditions of ether anesthesia, were simultaneously applied symmetrically to both exposed rats with an exposure of 10 seconds. Burn skin damage in rats was IIA-B grade dermal surface burn (according to the old classification IIIA grade) with a total area of $21-23 \%$ of the body surface with the development of burn shock. For morphological research the department of the duodenum was selected, a fragment of which was processed by conventional methods of light and electron microscopy. Semi-thin and ultrathin sections from epoxy blocks were obtained on an LKB ultratome
(Sweden). Ultra-thin sections after appropriate contrast were examined under a PEM-125K electron microscope. Semi-thin sections were stained with methylene and toluidine blue. Sections of paraffin blocks were stained with hematoxylin-eosin.

The main criteria for assessing damage enterocytes of the mucous membrane duodenum were the results of histological and ultrastructural data in dynamics after 7 , 14 , and 21 days after skin burns. Within the specified time rats were injected a single intraperitoneally large dose of sodium thiopental and removed from the experiment by decapitation.

\section{Results}

In the duodenum mucous membrane of the animals of the first experimental group 7 days after burn found dystrophic changes in most enterocytes while maintaining the shape of unevenly swollen and infiltrated by lymphocytes (as well as leukocytes) villi (Fig. 1). Columnar borderless enterocytes, goblet cells, and intestinal

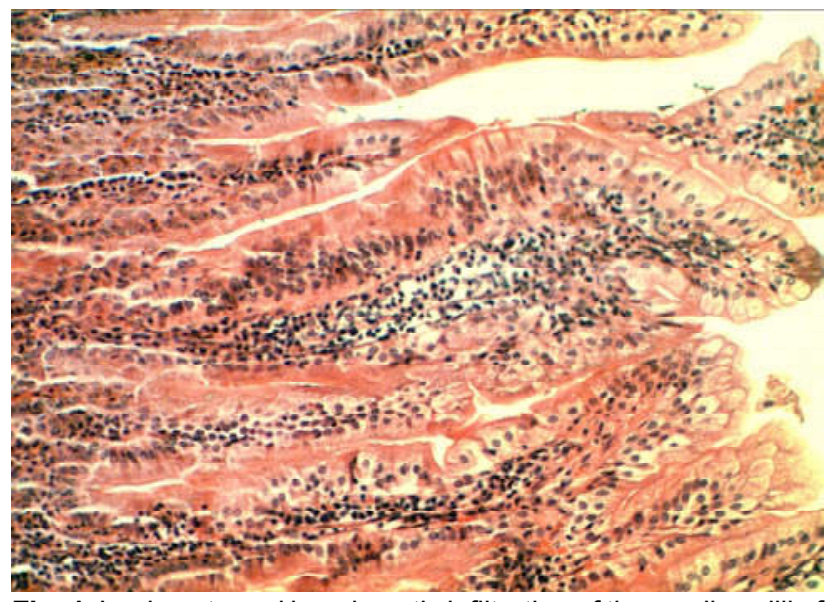

Fig. 1. Leukocyte and lymphocytic infiltration of the swollen villi of the duodenal mucosa of the first experimental group 7 days after burn. Hematoxylin-eosin. x60.

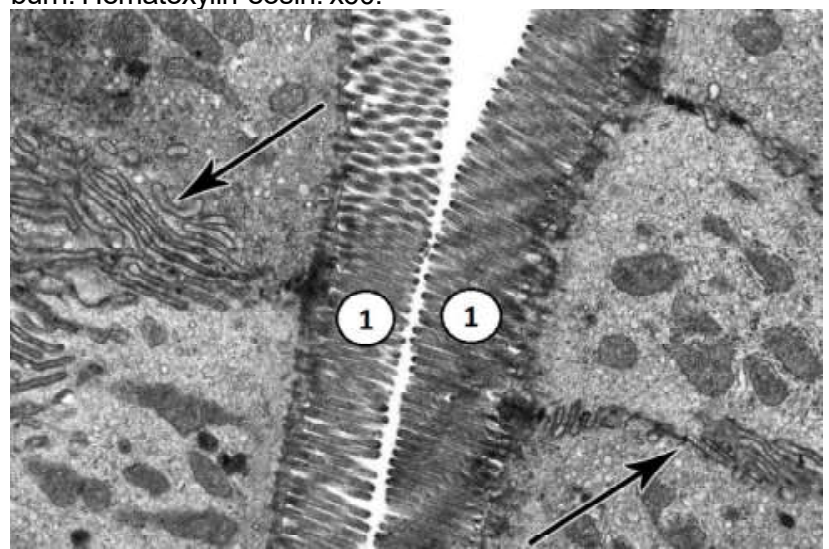

Fig. 2. Ultrastructural organization of enterocytes with a brush border in the mucous membrane of the duodenum of the rat under normal conditions (control group of animals). The arrows indicate the inter-digitization of the cytoplasmic processes of adjacent enterocytes. 1 - brush border. EM x10000. 
endocrinocytes were simultaneously altered. The described changes in the epithelial lining were accompanied by the expansion of the interepithelial spaces. These extensions revealed interepithelial lymphocytes, which also had pronounced damage to the structure. These morphological sings of the epithelial monolayer are significantly different from those under normal conditions.

In animals of the control group (Fig. 2), the apical portion of each columnar enterocyte with a brush border contains monofilaments, by means of which is formed dense intercellular contacts that isolate the lateral surface of enterocytes from the contents of the intestinal lumen. The cytoplasm of adjacent enterocytes has long thin processes that form interdigitations of complex shape along the contacting lateral surfaces of cells. Due to the availability of dense contacts and interdigitation of cytoplasmic processes, the maximum convergence of plasmalemma of adjacent enterocytes is ensured and the maximal decrease intercellular spaces in the epithelium. Under the conditions of preservation of the integrity of the epithelial monolayer, a characteristic single-type, saved mainly leaflike form of the villi of the mucous membrane duodenum.

In the mucous membrane of the duodenum of the animals of the first experimental group 7 days after burn, concomitant changes in the microcirculatory bed caused perivasal edema, leukocyte infiltration, diapedesis of erythrocytes, rupture of individual micro vessels with the formation of hemorrhages. In comparative analysis of the structural organization of the mucosa of the duodenum in this group of animals observed manifestations of adaptive processes. Detected the availability of a more pronounced folding of the mucous membrane. The villi are well developed, thickened, their own lamina includes a considerable number of lymphocytes.

Widespread phenomenon in this time interval is a variety of ultrastructural changes of enterocytes against the background of swelling of their cytoplasm (an indicator of which is the enlightenment of the cytoplasmic matrix): from the vacuolation of the tubules of the endoplasmic reticulum and damage to the mitochondria (manifestation is their intense swelling, fragmentation of the crust and inner membrane), to the complete destruction of organelles, the appearance of defects of plasmalemma and nuclear membrane.

In areas of enterocytes cytoplasm with partially lost brush border there are rounded autophagosomes and autophagolysosomes of different size with heteromorphic electron-dense contents (Fig. 3).

Morphological evidence of the initial stage of autophagy is the grouping of damaged cell organelles in certain loci of the cytoplasmic matrix and their sequestration by concentric coverage of the characteristic autophagosome structure - phagophore (double insulating membrane). In the future, autophagosomes merge with lysosomes and form autophagosomes with different electron density and structure (which is an indicator of the stages and efficiency

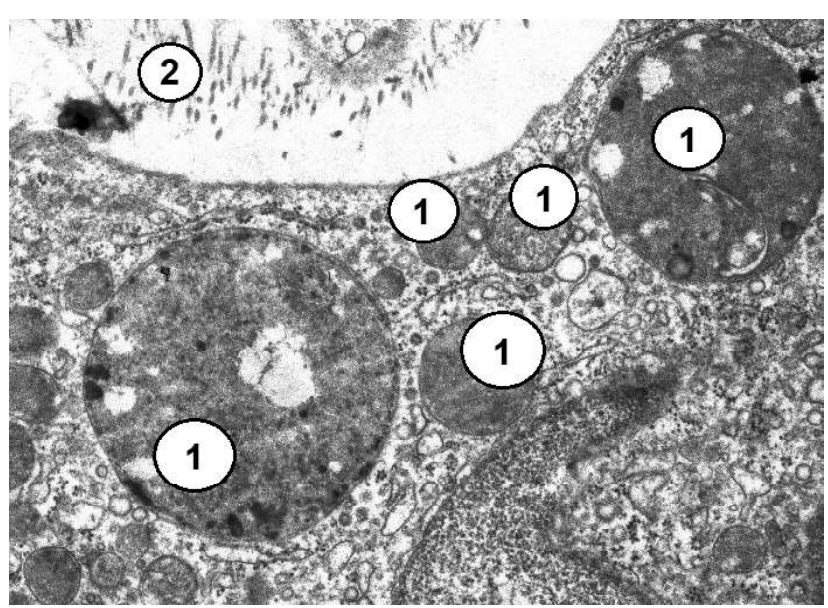

Fig. 3. Autophagosomes (1) of various sizes with heteromorphic electron-dense contents in the cytoplasm of enterocyte with the remnants of the brush border in the mucous membrane of the duodenum of the rat of the first experimental group 7 days after burn, 2 - the remnants of the brush border. EM x20000.

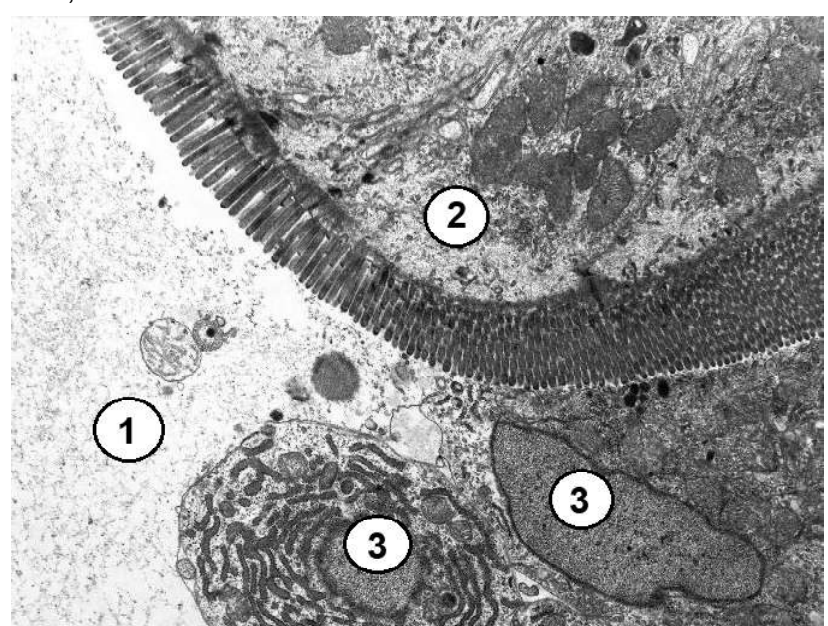

Fig. 4. Area of epithelial monolayer of enterocytes with preserved brush border and desquamated cells in the margins in the mucous membrane of the duodenum of the rat of the first experimental group 14 days after burn. 1 - intestinal lumen, 2 - cytoplasm of enterocyte with brush border, 3 - the nucleus of the desquamated cell. EM x10000.

of digestion of the sequestered material).

Digestion of the content of autophagolysosomes is accompanied by destruction of the inner membrane of the phagophore (under these conditions, the products of digestion are likely to be absorbed by the cytoplasm of the enterocyte). If part of the material remains undigested, then the autophagolysosome is transformed into an autophagic vacuole, which is directed to the plasmalemma of the apical region of the enterocyte and releases its contents outside.

In the animals of the first experimental group, erosion, ulcers, numerous small, and sometimes quite extensive hemorrhages were observed much more frequently than in the previous study period 14 days after the burn. In the population of the columnar enterocytes with the brush border increased the content of dystrophic altered cells, 


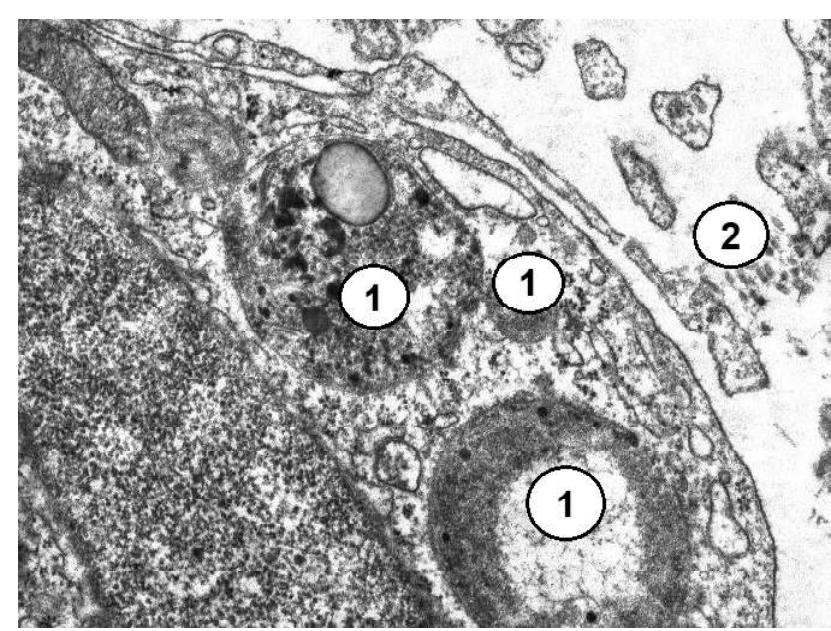

Fig. 5. Autophagosomes (1) of different size in the cytoplasm of enterocyte with a lost brush border in the mucous membrane of the duodenum of the rat of the first experimental group 14 days after burn, 2 - the remnants of the brush border. EM x20000.
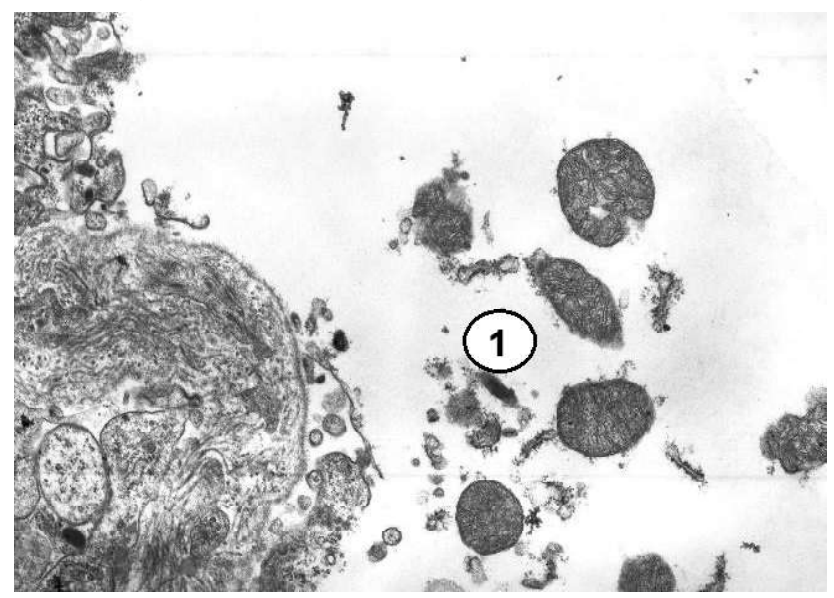

Fig. 6. Cellular detritus (1) in the intestinal lumen of the duodenum of the rat of the first experimental group 21 days after burn. EM $\mathrm{x} 20000$.

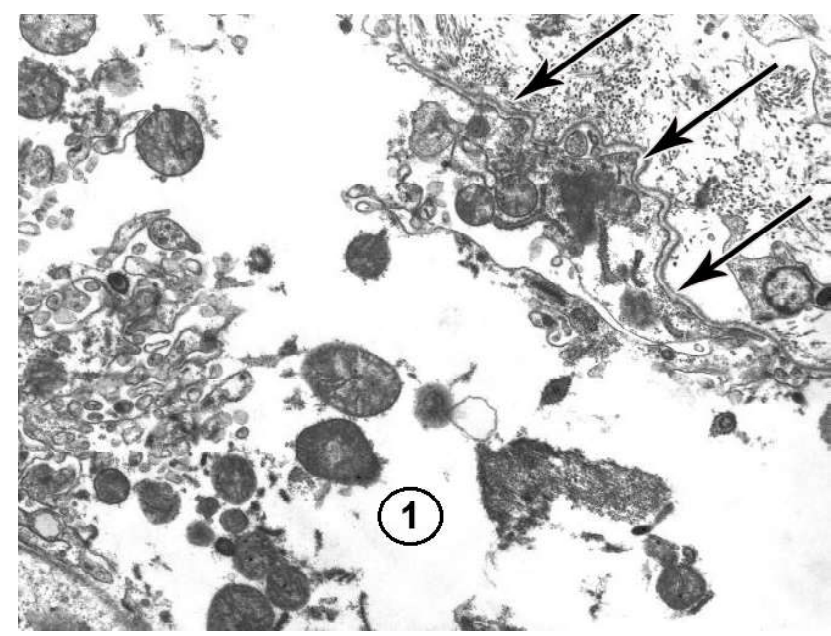

Fig. 7. Necrosis of the duodenal mucosa enterocytes of the rat of the second experimental group 14 days after burn. The arrows marked the "exposed" basement membrane of the epithelial monolayer. 1 - cellular detritus in the intestinal lumen. EM x20000. which were located not only in the upper, but also the middle and lower part of the villi.

The sections of the epithelial monolayer of enterocytes with preserved brush border alternated with areas free of brush border. Enterocytes of the epithelial monolayer were adjacent to desquamated cells of varying degrees of conservation (Fig. 4). In the apical part of most enterocytes with partially lost brush border were located groups of rounded autophagosomes and autophagolysosomes of different size and content (Fig. 5).

In the cytoplasm of many enterocytes with the presence of structural site defects of the plasmalemma and nuclear membrane in conjunction with local damage of the cytoplasmic matrix (which, given their variability, can probably be repaired) revealed signs of increased functional activity of organelles (evidence of moderate expansion of the tubules of the granular endoplasmic reticulum, an increase in the number of ribosomes, the presence of polyribosome, the aggregation of intact mitochondria, the integrity of the nucleus). In other enterocytes, at this time, the cytoplasm is vacuolated in the form of various enlargement of the tubules of the endoplasmic reticulum with enlightenment of their contents, vacuolar transformation of mitochondria, which is completed by complete necrotic destruction and cell fragmentation with the formation of cellular detritus.

In animals of the first experimental group after 21 days, after burns, morphologically focal atrophy of the mucous membrane was manifested by thickening and shortening of the villi; in some places they were completely absent. The erosions that were the result of enterocyte necrosis were often found (Fig. 6).

In animals of the second experimental group, subtotal necrosis of enterocytes with a brush border is widespread 7 days after burn, when, while maintaining part of the cytoplasm with an intact border, the cell area is subjected to necrotic degeneration, and the formed cell detritus with microvilli of the border enters the intestinal space.

14 days after burn in the mucous membrane of the duodenum of animals of the second experimental group, enterocytes in certain areas of the epithelial monolayer are subject to complete necrotic decay. In these areas, the basement membrane becomes "exposed" (Fig. 7). It is quite well preserved and even, it is somewhat thick compared to that of the norm (in the control group of rats).

The structural changes described above are accompanied by deformation and destruction of the villi of the duodenal mucosa (Fig. 8). The villi lose their typical leaf-like shape, often take on a "twisted" shape, and filamentous villi appear, surrounded by groups of desquamated enterocytes and cellular detritus.

21 days after burns in animals of the second experimental group in some parts of the mucous membrane of the duodenum of the crypt and villi are clearly deformed. The villi lose their typical cytoarchitectonics and have the appearance of clustered (and sometimes 


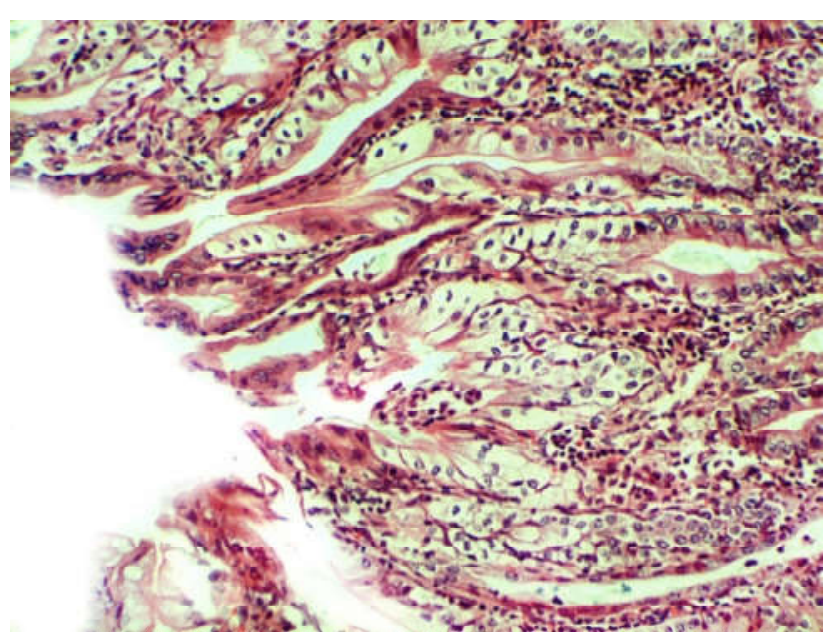

Fig. 8. Deformation and destruction of the villi of the duodenal mucosa of the second experimental group 14 days after burn. Hematoxylin-eosin. x60.

mushroom) enterocyte conglomerates of varying degrees of structural conservation.

\section{Discussion}

Diabetes mellitus and its related complications are becoming more common. The complex of gastrointestinal symptoms associated with diabetes is now known as diabetic enteropathy and can manifest as diarrhea, fecal incontinence, constipation, dyspepsia, nausea and vomiting [6]. The ancient theory that autonomic neuropathy is a major contributor to diabetic enteropathy has recently been supplemented by new theories of disease development. In particular, it is now considered [6] that hyperglycemia and its associated oxidative stress in neural networks (including nitric neurons and interstitial Cajal cells) play a central role in the development of diabetic enteropathy. The authors of the latest (at the time of publication) scientific review article "Diabets and the small intestine" [6] indicate that the latest scientific results are promising, but there is still a great need for further studies on the pathogenesis of diabetic enteropathy.

Many unresolved issues remain regarding the role of structural and functional alterations of the small intestine in the pathogenesis of burn disease, and, in particular, dysfunction in the context of burns of the intestinal epithelial barrier.

The data obtained indicate the structural manifestations of a barrier violation (destruction of dense interepithelial contacts, disappearance of interdigitations of cytoplasmic processes of adjacent enterocytes) in burn skin injury under experimental streptozotocin-induced diabetes. In addition, we confirmed the Huang Ya et al. data [11] regarding the involvement of autophagic processes in the development of gradual structural disorganization of the intestinal epithelial barrier, but unlike the authors, we consider their manifestation of an adaptive response.

It should be noted that the role of autophagy in cell death today by researchers treated quite contradictorily [11]. According to modern data [1], autophagy is the process of digestion of its own distorted organelles and sections of the cytoplasm by lysosomes (thus autophagy is both a type of programmed cell death and a strategy for cell survival by recycling cellular material). Thus, the adaptive response of the duodenal mucosa enterocytes to the destructive effects of burn disease factors involves the use as part of the plastic and energy resources of the degraded cellular material to repair the damaged enterocyte and to maintain its viability. Under the conditions of our experiment in rats of the first experimental group, the course of structural changes of enterocytes of the duodenal mucosa is slow enough to include the adaptive mechanism of autophagy of distorted organelles. In the animals of the second experimental group, destruction of cytoplasmic and organelle enterocyte sites (due to the summation of the factors of burn disease and diabetes) is accelerated and cells die by necrosis.

Summarizing we can say that in the duodenal mucosa of the second experimental group, the dynamics of morphological changes during different periods after burns ( 7 days - the stage of shock and early toxemia; 14 days - the stage of late toxemia; 21 days - the stage of septicemia) differ from animals of the first experimental group. Comparison of the obtained data with the previously revealed ones suggests that the time intervals and the nature of adaptive changes of the duodenal mucosa are largely prolonged and worsened. Significant lesions of the mucous membrane should lead to disruption of the processes of the digestive system, parietal digestion and absorption, as well as immunological protection (considering that the mucous membranes are the first zone of contact of the body with the antigens of the environment and the leading link of immune protection, immune defenses), affects the condition of the body of burned persons and, to a large extent, determines the development of burn disease, as well as the course of diabetes.

The prospect of further research in this area is related to the study of the effects on the duodenum of drugs that reduce the intoxication of the body and blood sugar level.

\section{Conclusions}

The results of the studies showed that the base of damage to the duodenal mucosa enterocytes consist of deep destructive changes, which after 21 days (in the stage of septicotoxemia), as a rule, are not reverse and develop on the background of significant intoxication of the body.

The structural changes of the enterocytes detected under the experiment were evidence of a violation of the structural integrity of the intestinal epithelial barrier. In animals of the first and (more) of the second experimental groups, the damaged epithelium of the duodenal mucosa critically weakens the adequacy of its function as an interface between the mucous membrane and the environment of the intestinal lumen, and is unable to structurally provide the reliability of antigenic toxicogenic bar. 
In the mucous membrane of the duodenum in burn injury of the skin associated with diabetes is worsening of the manifestations of the adaptive reaction and prolongation of

\section{References}

[1] Anding, A. L., \& Bachrecke, E. H. (2015). Autophagy in cell life and cell death. Curr. Top. Dev. Biol., 114, 67-91. doi: 10.1016/ bs.ctdb.2015.07.012.

[2] Cherkasov, V. G., Kovalchuk, A. I., Dzevulskaya, I. V., Malikov, A. V., Lakhtadyr, T. V., \& Matkivskaya, R. M. (2015). Structural transformations in the internal organs with infusion therapy for burn disease. Medical Science of Ukraine, 11(3-4), 4-11.

[3] Dzevulska, I. V., Kovalchuk, O. I., Cherkasov, E. V., Majewskyi, O. Ye., Shevchuk, Yu. G., Pastukhova, V. A., \& Kyselova, T. M. (2018). Influence of lactoproteinum solution with sorbitol on DNA content of cells of endocrine glands on the background of skin burn in rats. World of Medicine and Biology, 64 (2), 33-39. doi: 10.26724/2079-8334-2018-2-64-33-39

[4] Evers, L. H. (2010). The biology of burn injury. Exp. Dermatol., 19(2), 9, 777-783. doi: 10.1111/j.1600-0625.2010.01105.x

[5] Galunko, G. M. (2017). Histological changes in the small intestine in the advanced stages of burn diseases. World of Medicine and Biology, 3(61), 90-96. doi: 10.26724/ 2079-8334-2017-361-90-96

[6] Gotfried, J., Priest, S., \& Schey, R. (2017). Diabetes and the small intestine. Curr. Treat. Options. Gastroenterol., 15(4), 490-507. doi: 10.1007/s11938-017-0155-x

[7] Gunas, I., Dovgan, I, \& Masur, O. (1997). Method of intermal burn trauma correction by means of cryoinfluence. Abstracts are presented in zusammen mit der Polish Anatomical Society with the participation of the Association des Anatomistes Verhandlungen der Anatomishen Geselleschaft, Olsztyn (p. 105). Jena-Munchen: Der Urban \& Fisher Verlag.

[8] Gunas, I. V., Guminskiy, Yu. I., Ocheretna, N. P., Lysenko, D. A., Kovalchuk, O. I., Dzevulska, I. V., \& Cherkasov, E. V. (2018). Indicators cell cycle and DNA fragmentation of spleen cells in early terms after thermal burns of skin at the background of introduction $0.9 \% \mathrm{NaCl}$ solution. World of Medicine and Biology, 1(63), 116-120. doi: 10.26.724/2079-8334-2018-1-63-116-120

[9] Gunas, I. V., Kovalchuk, O. I., Cherkasov, V. G., \& Dzevulska, I. V. (2014). Structural aspects of the organs adaptive changes of the neuroimundocrine system in the treatment of burn diseases with combined hyperosmolar solutions. Galician Medical Herald, 21(2), 21-26.

[10] Haagsma, J. A., Greatz, N., \& Bolliger, I. (2016). The global burden of injury: incidence, mortality, disability - adjusted life destructive processes, which is accompanied by a violation of intercellular interactions in the cytoarchitectonically altered and deformed crypts and villi.

years and time trends from the Global Burden of Diseases study 2013. Injury Prevention, 22(1), 3-18.

[11] Huang, Ya., Feng, Ya., Wang, Yu., Wang, Pei., Wang, Fe., \& Ren, Hui. (2018). Severe burn-induced intestinal epithelial barrier dysfunction is associated with endoplasmic reticulum stress and autophagy in mice. Front Physiol., 9, 441. doi: 10.3389/fphys.2018.00441

[12] Jeschke, M. G., Pinto, R., \& Kraft, R. (2015). Inflammation and the Host Response to Injury Collaborative Research Program. Morbidity and survival probability in burn patients in modern burn care. Crit. Care. Med., 43(2), 4, 808-815. NCT00257244

[13] Kallinen, O., Maisniemi, K., Bohling, T., Tukiainen, E., \& Koljonen, V. (2012). Multiple organ failure as a cause of death in patients with severe burns. J. Burn Care Res., 33(2), 206-211. doi: 10.1097/BCR.0b013e3182331e73

[14] Kearney, L., Francis, E. C., \& Clover, A. J. (2018). New technologies in global burn care - a review of recent advances. Int. J. Burns Trauma, 8(4), 77-87. PMID: 30245912

[15] Natrus, L.V., Ryzhko, I. N., Kozak, A. I., Kryvosheieva, O. I., \& Stechenko, L. A. (2017). Ultrastructural base of the connective tissue skin' cells interactions at burn injury in the hyperglycemic white rats. World of Medicine and Biology, 4(62), 157-162. doi: 10.26724/2079-83342017-4-62-157-162

[16] Netyukhailo, L. G., Kharchenko, A. G., \& Kostenko, S. V. (2011). Pathogenesis of burn disease (in 2 parts). World of Medicine and Biology, 1, 127-131, 131-135.

[17] Regas, F. C., \& Ehrlich, H. P. (1992). Elucidating the vascular response to burns with a new rat model. J. Trauma, 32(5), 557-563.

[18] Smolle, Ch., Cambiaso-Daniel, J., \& Forbes, A. A. (2017). Recent trends in burn epidemiology woredwide: A systemic review. Burns, 43(2), 249-257. doi: 10.1016/j.burns.2016.08.013.

[19] Swanson, J. W., Otto, A. M., Gibran, N. S., Klein, M. B., Kramer, C. B., Heimbach, D. M., \& Pham, T. N. (2013). Trajectories to death in patients with burn injury. J. Trauma Acute Care Surg., 74(1), 282-288. doi: 10.1097/TA.0b013e3182788a1c

[20] Timmers, T. K., Verhofstad, M. H., \& Leenen, L. P. (2015), Intensive care organisation: Should there be a separate intensive care unit for critically injured patients? World Journal of Critical Care Medicine, 4, 240-243. doi: 10.5492/ wjccm.v4.i3.240

\section{СТРУКТУРНІ ЗМІНИ ЕНТЕРОЦИТІВ СЛИЗОВОЇ ОБОЛОНКИ ДВАНАДЦЯТИПАЛОЇ КИШКИ ЩУРІВ ПРИ ОПІКОВІЙ ТРАВМІ ШКІРИ ЗА УМОВ ЕКСПЕРИМЕНТАЛЬНОГО СТРЕПТОЗОТОЦИН-ІНДУКОВАНОГО ЦУКРОВОГО ДІАБЕТУ Черкасов В.Г., Тімошенко І.О.}

Робота присвячена вивченню структурних змін ентероцитів у слизовій оболонці дванадцятипалої кишки при опіковій травмі шкіри щура за умов експериментального стрептозотоцин-індукованого иукрового діабету. Дослідження проведено на лабораторних білих статевозрілих щурах-самцях масою 180-210 г. Контрольну групу склала 21 тварина без соматичноі патології, першу експериментальну групу склали 21 щур з опіковою травмою шкіри, другу експериментальну групу склали 21 щур з опіком шкіри та експериментальним стрептозотоцин-індукованим діабетом. Модель експериментального цукрового діабету відтворювали шляхом введення щурам стрептозотоцину внутрішньоочеревинно одноразово в дозі 50 мг/ке. При експериментальному моделюванню опіку шкіри дві мідні пластинки у вигляді еліпсу витримували у воді при $100^{\circ} \mathrm{C} 10$ хвилин i, за умов ефрірного наркозу, накладали одночасно симетрично на обидві оголені частини тіла щурів з експозицією 10 секунд. Опікове пошкодження шкіри у шурів складало ІІА-Б ступеня - дермального поверхневого опіку (за старою класифікацією ІІІА ступінь) загальною площею 21-23\% поверхні тіла з розвитком опікового шоку. Для морфологічних досліджень було вилучено відділ дванадцятипалої кишки, фррагменти якого були досліджені методами світлової та електронної мікроскопії. Основними критеріями оцінки пошкодження ентероцитів слизової оболонки дванадиятипалої кишки стали результати дослідження гістологічних та ультраструктурних даних в динаміці через 7, 14, та 21 добу після опіку шкіри. Результати проведених 
досліджень показали, що в основі пошкоджень ентероцитів слизової оболонки дванадиятипалої кишки лежать глибокі деструктивні зміни, які через 21 добу (в стадії септикотоксемії), як правило, мають незворотній характер і розвиваються на фонні значної інтоксикації організму. При опіковій травмі шкіри, асоційованій з иукровим діабетом, в слизовій оболонці дванадиятипалої кишки погіршується прояв адаптивної реакції і пролонгуються деструктивні процеси, що супроводжується порушенням міжклітинних взаємодій в цитоархітектонічно змінених та дефрормованих ворсинках і криптах.

Ключові слова: опікова травма, стрептозотоцин-індукований цукровий діабет, морфологічні зміни дванадиятипалої кишки.

СТРУКТУРНЫЕ ИЗМЕНЕНИЯ ЭНТЕРОЦИТОВ СЛИЗИСТОЙ ОБОЛОЧКИ ДВЕНАДЦАТИПЕРСТНОЙ КИШКИ ПРИ ОЖОГОВОЙ ТРАВМЕ КОЖИ В УСЛОВИЯХ ЭКСПЕРИМЕНТАЛЬНОГО СТРЕПТОЗОТОЦИН-ИНДУЦИРОВАННОГО САХАРНОГО ДИАБЕТА Черкасов В.Г., Тимошенко И.А.

Работа посвящена изучению структурных изменений энтероцитов в слизистой оболочке двенадцатиперстной кишки при ожоговой травме кожи крысы в условиях экспериментального стрептозотоцин-индуцированного сахарного диабета. Исследование проведено на лабораторных белых половозрелых крысах-самцах массой 180-210 г. Группу контроля составили 21 животное без соматической патологии, первую экспериментальную группу составила 21 крыса с ожоговой травмой кожи, вторую экспериментальную группу составила 21 крыса с ожогом кожи и экспериментальным стрептозотоцининдуцированным диабетом. Модель экспериментального сахарного диабета воспроизводили путем введения крысам стрептозотоцина внутрибрюшинно однократно в дозе 50 мг/ке. При экспериментальном моделировании ожога кожи две медные пластинки в виде эллипса выдерживали в воде при $100^{\circ} \mathrm{C} 10$ минут и, в условиях эфирного наркоза, накладывали одновременно симметрично на обе обнаженные части тела крыс с экспозицией 10 секунд. Ожоговое повреждение кожи у крыс составляло ІІА-Б степени - дермального поверхностного ожога (по старой классификации IIIA степень) общей площадью 21-23\% поверхности тела с развитием ожогового шока. Для морфологических исследований изымали отдел двенадцатиперстной кишки, фррагменты которого были исследованы общепринятыми методами световой и электронной микроскопии. Основными критериями оценки повреждения энтероцитов слизистой оболочки двенадцатиперстной кишки стали результаты исследования гистологических и ультраструктурных данных в динамике через 7, 14 и 21 сутки после ожога кожи. Результаты проведенных исследований показали, что в основе повреждений энтероцитов слизистой оболочки двенадцатиперстной кишки лежат глубокие деструктивные изменения, которые через 21 день (в стадии септикотоксимии), как правило, имеют необратимый характер и развиваются на фоне значительной интоксикации организма. При ожоговой травме кожи, ассоциированной с сахарным диабетом, в слизистой оболочке двенадиатиперстной кишки ухудшаются проявления адаптивной реакции и пролонгируются деструктивные процессы, сопровождающиеся нарушением межклеточных взаимодействий в цитоархитектонически измененных и деформированных ворсинках и криптах.

Ключевые слова: ожоговая травма, стрептозотоцин-индуцированный сахарный диабет, морфологические изменения двенадцатиперстной кишки. 